\title{
Electrophilic Aromatic Acylation Synthesis of Wholly Aromatic Polyketones Composed of 2,2'-Dimethoxybiphenylene Units
}

\author{
Noriyuki Yonezawa, ${ }^{\dagger}$ Shin-ichiro Mori, ${ }^{*}$ Shiro MiYata, ${ }^{*}$ \\ Yuriko UEHA-ANYASHIKI, ${ }^{*}$ Shou Ming Wu, and Katsuya MAEYAMA \\ Department of Organic and Polymer Materials Chemistry, Tokyo University of Agriculture and Technology, \\ Koganei, Tokyo 184-8588, Japan \\ ${ }^{*}$ Research and Development Division, NKK Corporation, Kawasaki-ku, Kawasaki, Kanagawa 210-0855, Japan
}

(Received August 8, 2003; Accepted October 17, 2003)

\begin{abstract}
Wholly aromatic polyketones have been successfully synthesized via $\mathrm{AlCl}_{3}$-mediated FriedelCrafts acylation polymerization and $\mathrm{P}_{2} \mathrm{O}_{5}-\mathrm{MsOH}$ mediated direct condensation polymerization between $2,2^{\prime}$ dimethoxybiphenyl (1a), an excellent acyl-acceptant monomer for electrophilic aromatic acylation polymerization, and arenedicarboxylic acid derivatives.

KEY WORDS Aromatic Polyketones / Noncrystal Polymers / Friedel-Crafts Acylation / Wholly Aromatic Polyketones /
\end{abstract}

Aromatic polyketones have attracted much attention in respect of their excellent chemical and physical properties. While there are a lot of reports on aromatic polyketones, ${ }^{1,2}$ almost all of them are classified as aromatic poly(ether ketone)s, i.e., the aromatic polymers containing ether linkages together with ketonic carbonyl groups in the main chains. On the contrary, there are only a few reports on wholly aromatic polyketones, i.e. aromatic polyketones without ether linkages in the main chain. ${ }^{3-7}$ Although nucleophilic aromatic substitution is the most effective chain elongation reaction for the syntheses of aromatic poly(ether ketone)s, it is inapplicable for the syntheses of wholly aromatic polyketones. In this course, the less effective methods, i.e., electrophilic aromatic acylation such as FriedelCrafts acylation and aromatic coupling reaction ${ }^{8,9}$ are the residual choices of the protocol to wholly aromatic polyketones.

As one of the typical example of electrophilic aromatic acylation polymerization, Ueda and his coworkers have reported the efficient synthetic method for aromatic poly(ether ketone)s with the aid of phosphrous pentoxide-methanesulfonic acid mixture $\left(\mathrm{P}_{2} \mathrm{O}_{5}\right.$ $\mathrm{MsOH}$ ) as a condensing agent and solvent. ${ }^{10-13} \mathrm{P}_{2} \mathrm{O}_{5}$ $\mathrm{MsOH}$ mediated direct condensation is apparently preferable to $\mathrm{AlCl}_{3}$-mediated polymerization when the producing polyketones have low solubility to organic solvents. We have also reported the synthesis of aromatic copoly(ether ketone)s having good adhesion property to steel surface. ${ }^{14}$

In the course of the study on the synthesis of aromatic polyketones, we have found that electrophilic aromatic substitution polymerization of $2,2^{\prime}$-dimethoxybiphenyl (1a) and arenedicarboxylic acid derivatives readily gives wholly aromatic polyketones having appreciable molecular weights. In this paper, we would like to report that 2,2'-dimethoxybiphenyl (1a) is an excellent regioselective acyl-acceptant monomer having continuous reactivity and high regioselectivity in $\mathrm{AlCl}_{3}$ mediated Friedel-Crafts-type polymerization and in $\mathrm{P}_{2} \mathrm{O}_{5}-\mathrm{MsOH}$ mediated direct condensation polymerization. ${ }^{15}$

\section{EXPERIMENTAL}

\section{General}

${ }^{1} \mathrm{H}$ NMR spectra were recorded on a JEOL GX-270 $(270 \mathrm{MHz})$. Chemical shifts are expressed in ppm relative to internal standard of $\mathrm{Me}_{4} \mathrm{Si}(\delta, 0.00)$ or DMSO- $d_{6}$ $(\delta, 2.49)$. Inherent viscosities $\left(\eta_{\text {inh }}\right)$ were determined by measurement of the flow time of polymer solution in concentrated $\mathrm{H}_{2} \mathrm{SO}_{4}\left(0.3 \mathrm{~g} \mathrm{dL}^{-1}\right)$ at $30^{\circ} \mathrm{C}$ using an Ostwald viscometer. The glass transition temperatures ( $T_{\mathrm{g}}$ 's) were determined on the basis of DSC curves. DSC curves were recorded on a SEIKO DSC-200 differential scanning calorimeter with a heating rate of $10 \mathrm{~K} \mathrm{~min}^{-1}$ under nitrogen. Thermal degradation temperature $\left(T_{\mathrm{d}}\right)$ was determined on the basis of a TGA thermogram. The TGA thermogram was recorded on a SEIKO TG/DTA-200 thermogravimeter with a heating rate of $10 \mathrm{~K} \mathrm{~min}^{-1}$.

2,2'-Dimethoxybiphenyl (1a) and 4,4'-dimethoxybiphenyl (1b) were prepared via dimethylation of the corresponding biphenols with $\mathrm{Me}_{2} \mathrm{SO}_{4}$. 2,2'Dimethoxydiphenyl ether (1c) was prepared via Ullmann-type reaction of $o$-methoxyphenol $(3 \mathrm{mmol})$, 
$o$-bromoanisole $(2.5 \mathrm{mmol})$, potassium hydroxide $(2.2 \mathrm{mmol})$, and cupper powder $(5 \mathrm{mg})$ at $180^{\circ} \mathrm{C}$ for $2 \mathrm{~h}$ in a $38 \%$ yield. ${ }^{1} \mathrm{HNMR}(270 \mathrm{MHz}) \delta$ $\left(\mathrm{CDCl}_{3}\right): 3.85(6 \mathrm{H}, \mathrm{s}), 6.77-7.13(8 \mathrm{H}, \mathrm{m})$ ppm. 2,2' Bis(trifluoromethyl)biphenylene-4,4' -dicarboxylic acid (2d) was prepared according to our previous paper. ${ }^{16-19} \mathrm{P}_{2} \mathrm{O}_{5}-\mathrm{MsOH}$ was prepared according to Eaton's procedure. ${ }^{20}$

$\mathrm{P}_{2} \mathrm{O}_{5}-\mathrm{Ms} \mathrm{OH}$ Promoted Polymerization of 2,2'-Dimethoxybiphenyl (1a) and Dicarboxylic Acid 2

A solution of 2,2'-dimethoxybiphenyl (1a, $214 \mathrm{mg}$, $1.0 \mathrm{mmol})$ and dicarboxylic acid $(2,1.0 \mathrm{mmol})$ in $\mathrm{P}_{2} \mathrm{O}_{5}$ $\mathrm{MsOH}(3 \mathrm{~g})$ was stirred for $24 \mathrm{~h}$ at $60^{\circ} \mathrm{C}$. The reaction mixture was diluted with $\mathrm{MsOH}$ and the resulting solution was poured into saturated aqueous sodium carbonate to separate out a white solid. The solid was collected by suction filtration and dried in vacuo at $120^{\circ} \mathrm{C}$ to give polymer $\mathbf{3}$.

Polymer 3a: IR $v(\mathrm{KBr}): 1651,1593,1241 \mathrm{~cm}^{-1}$. ${ }^{1} \mathrm{HNMR}(270 \mathrm{MHz}) \delta$ (DMSO- $\left.d_{6}\right): 3.80(6 \mathrm{H}, \mathrm{s}), 7.05-$ $7.22(6 \mathrm{H}, \mathrm{m}), 7.60-7.85(8 \mathrm{H}, \mathrm{m}) \mathrm{ppm}$. Anal. Calc. for $\mathrm{C}_{28} \mathrm{H}_{20} \mathrm{O}_{5}$ : C, $77.06 \%$; H, 4.59\%. Found: $\mathrm{C}, 75.52 \%$; $\mathrm{H}, 4.71 \%$.

$\mathrm{AlCl}_{3}$-Promoted Polymerization of 2,2'-Dimethoxybiphenyl (1a) and Dicarboxylic Acid Dichloride 5

To a solution of 2,2'-dimethoxybiphenyl (1a, $214 \mathrm{mg}, 1.0 \mathrm{mmol}$ ) and dicarbonyl dichloride (5, $1.0 \mathrm{mmol})$ in 1,2-dichloroethane $(4 \mathrm{~mL}), \mathrm{AlCl}_{3}$ was added by portions at $5^{\circ} \mathrm{C}$ under nitrogen atmosphere. The reaction mixture was stirred for $1 \mathrm{~h}$ at $5^{\circ} \mathrm{C}$, warmed up to $15^{\circ} \mathrm{C}$, and stirred further for $24 \mathrm{~h}$ at $15^{\circ} \mathrm{C}$. The reaction was quenched by addition of methanol to separate out white precipitates. The precipitates were collected by suction filtration and dried in vacuo at $120^{\circ} \mathrm{C}$ to give a white solid of polymer 6 . Polymer $6 \mathbf{b}$ : IR $v$ (KBr): 1655, 1595, $1257 \mathrm{~cm}^{-1} .{ }^{1} \mathrm{H}$ NMR $(270 \mathrm{MHz}) \delta$ (DMSO- $\left.d_{6}\right)$ : $3.80-3.90(6 \mathrm{H}, \mathrm{m}), 7.15-7.30(2 \mathrm{H}, \mathrm{m})$, 7.68-7.90 (8 H, m) ppm. Anal. Calc. for $\mathrm{C}_{22} \mathrm{H}_{16} \mathrm{O}_{4}$ : C, $76.74 \%$; H, 4.65\%. Found: C, 75.59\%; H, 4.76\%.

\section{RESULTS AND DISCUSSION}

\section{Reactivity of Several Acyl-acceptant Monomers}

As mentioned above, Ueda and his coworkers have reported $\mathrm{P}_{2} \mathrm{O}_{5}-\mathrm{MsOH}$ mediated electrophilic aromatic acylation polymerization of dicarboxylic acids containing phenyl ether structures such as 4,4'-oxybis(benzoic acid) (2a) with arenes to yield aromatic poly(ether ketone)s having high inherent viscosities..$^{10}$ They describe that phenyl ether structure in dicarboxylic acid is indispensable to regioselective acylation. ${ }^{10}$
According to this method, four kinds of electronrich symmetrical arenes $(\mathbf{1 a}-\mathbf{1 d})$ were subjected to electrophilic aromatic acylation polymerization with 4,4'-oxybis(benzoic acid) (2a). The degree of polymerization was assessed on the basis of the inherent viscosity in a concentrated $\mathrm{H}_{2} \mathrm{SO}_{4}$ solution at $30{ }^{\circ} \mathrm{C}$. The results are summarized in Table I. When 2,2'-dimethoxybiphenyl (1a) was allowed to react with carboxylic acid 2a, the highest-molecular-weight poly(ether ketone) was obtained $\left(\eta_{\text {inh }}, 0.49 \mathrm{dL} \mathrm{g}^{-1}\right)$. 2,2'-Dimethoxydiphenyl ether (1c) also shows effective reactivity for electrophilic aromatic acylation polymerization to give a poly(ether ketone) having moderate inherent viscosity. One of the common structural characteristics in the two effective acyl-acceptant monomers, $\mathbf{1 a}$ and $\mathbf{1 c}$, is that two methoxy groups are situated at the $o$-positions. The two methoxy groups of monomer 1a not only activate the reactivity through electron-donating effect but also bring a twist in the biphenylene unit, which probably prevent the resulting

Table I. $\mathrm{P}_{2} \mathrm{O}_{5}-\mathrm{MsOH}$ mediated polymerization of arene $\mathbf{1}$ and 4,4'-oxybis(benzoic acid) (2a) ${ }^{\mathrm{a}}$

\begin{tabular}{ccc}
\hline Arene 1 & Polymer 3 & $\eta_{\text {inh }} / \mathrm{dL} \mathrm{g}^{-1 \mathrm{~b}}$ \\
\hline 1a & 3a & 0.49 \\
1b & 3b & 0.14 \\
1c & 3c & 0.34 \\
1d & 3d & 0.12 \\
\hline
\end{tabular}

${ }^{\mathrm{a}}$ Reaction conditions, arene 1: $1 \mathrm{mmol}, 4,4^{\prime}-$ oxybis(benzoic acid) (2a): $1 \mathrm{mmol}, \mathrm{P}_{2} \mathrm{O}_{5}-\mathrm{MsOH}$ : $3 \mathrm{~g}, 60^{\circ} \mathrm{C}, 24 \mathrm{~h}$. ${ }^{\mathrm{b}}$ Inherent viscosity was determined in a concentrated $\mathrm{H}_{2} \mathrm{SO}_{4}$ solution $(0.3 \mathrm{~g}$ $\mathrm{dL}^{-1}$ ) at $30^{\circ} \mathrm{C}$.

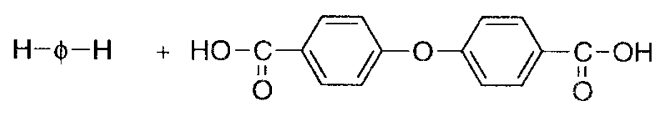

1

2a

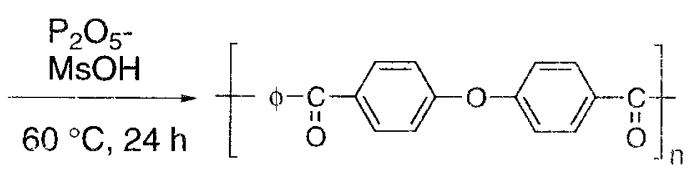

3

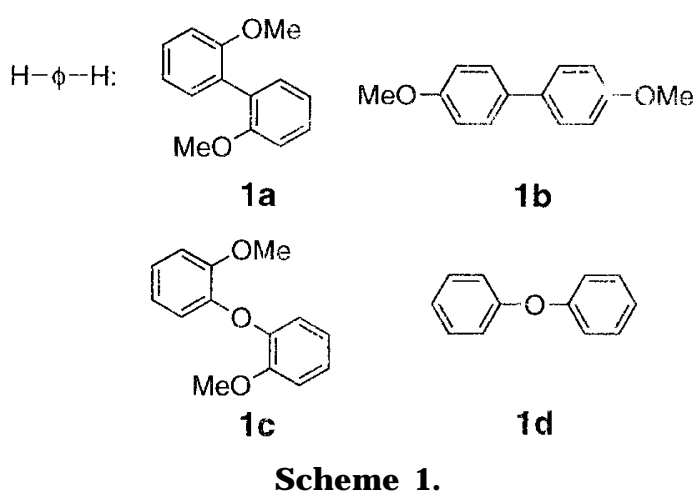


oligomer from aggregation and precipitation.

$\mathrm{P}_{2} \mathrm{O}_{5}-\mathrm{MsOH}$ Mediated Polymerization of 2,2'Dimethoxybiphenyl (1a) with Several Arenedicarboxylic Acid Derivatives

2,2'-Dimethoxybiphenyl (1a), one of the most effective acyl-acceptant monomers for $\mathrm{P}_{2} \mathrm{O}_{5}-\mathrm{MsOH}$ mediated electrophilic aromatic acylation polymerization with 4,4'-oxybis(benzoic acid) (2a), also gives polyketones in the reaction with several arenedicarboxylic acids having no phenyl ether structures. When terephthalic acid (2b) or isophthalic acid (2c) was allowed to react with 2,2'-dimethoxybiphenyl (1a) in $\mathrm{P}_{2} \mathrm{O}_{5}-\mathrm{MsOH}$, a polyketone with rather moderate molecular weight was obtained. The less reactivity in $\mathrm{P}_{2} \mathrm{O}_{5}-\mathrm{MsOH}$ mediated polymerization of $2,2^{\prime}-$ dimethoxybiphenyl (1a) with terephthalic acid (2b) or isophthalic acid (2c) probably depends on insufficient activation of these carboxylic acids by $\mathrm{P}_{2} \mathrm{O}_{5}$ $\mathrm{MsOH}$ for sustainable acylation. On the other hand, biphenylenedicarboxylic acid bearing $\mathrm{CF}_{3}$ groups $(\mathbf{2 d})$ gave a polymer having low inherent viscosity via $\mathrm{P}_{2} \mathrm{O}_{5}$ $\mathrm{MsOH}$ mediated direct polycondensation with biphenyl 1a. The obtained polyketone is, however, estimated to have an appreciable molecular weight because in the ${ }^{1} \mathrm{HNMR}$ spectrum of the resulting polymers, the signal of the proton at the terminal unit is negligibly small against that of methoxy group. Accordingly, lower inherent viscosity of the resulting polyketone (4d) probably owes to weakness of intermolecular interaction between the polymer chains strongly polarized by $\mathrm{CF}_{3}$ substituents. ${ }^{16,17,21}$ The excellent reactivity in the $\mathrm{P}_{2} \mathrm{O}_{5}-\mathrm{MsOH}$ mediated polymerization of 2,2'-dimethoxybiphenyl (1a) with carboxylic acid 2d depends on electron-deficiency of carboxy groups of dicarboxylic acid $\mathbf{2 d}$ through strong electronwithdrawing effect of $\mathrm{CF}_{3}$ group. Then, for realization of regioselective electrophilic aromatic acylation, milder activation such as transformation of the carboxy group into mixed acid anhydride type acylinium ion equivalent is preferable. Therefore, activation by $\mathrm{P}_{2} \mathrm{O}_{5}$ $\mathrm{MsOH}$ through the formation of mixed acid anhydride equivalent is more effective than that via Friedel-Crafts type activation by $\mathrm{AlCl}_{3}$.

Friedel-Crafts-type Polymerization of 2,2-Dimethoxybiphenyl (1a) with Dicarboxylic Acid Dichloride 5

$\mathrm{AlCl}_{3}$-promoted Friedel-Crafts acylation polymerization of 2,2'-dimethoxybiphenyl (1a) and terephthaloyl chloride $(\mathbf{5 b})$ in 1,2-dichloroethane at $15^{\circ} \mathrm{C}$ afforded polymer $\mathbf{6 b}$ with an inherent viscosity of $0.68 \mathrm{dL} \mathrm{g}^{-1}$. When the reaction was performed at $30^{\circ} \mathrm{C}$, the inherent viscosity of the resulting polyke-

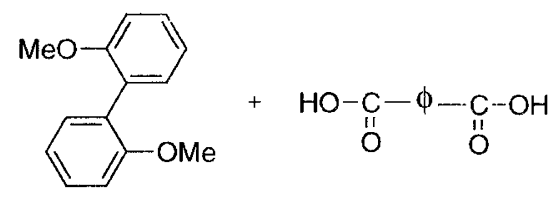

$1 \mathrm{a}$
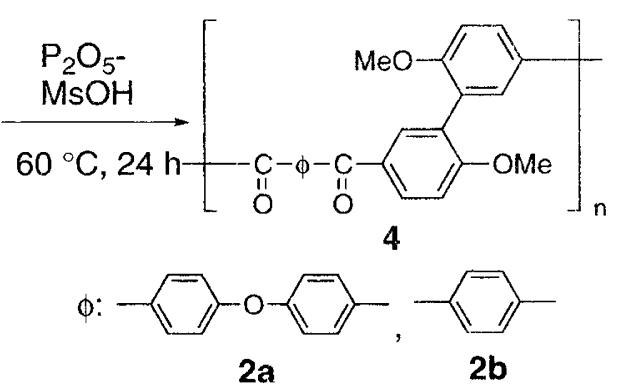

$2 a$

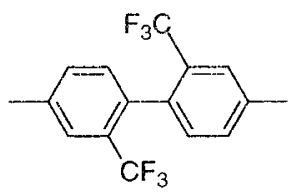

2c

2d

Scheme 2.

Table II. $\mathrm{P}_{2} \mathrm{O}_{5}-\mathrm{MsOH}$ mediated polymerization of 2,2'-dimethoxybiphenyl (1a) and dicarboxylic acid $2^{\mathrm{a}}$

\begin{tabular}{ccc}
\hline Carboxylic acid 2 & Yield/\% & $\eta_{\text {inh }} / \mathrm{dL} \mathrm{g}^{-1 b}$ \\
\hline $\mathbf{2 a}$ & 99 & 0.49 \\
$\mathbf{2 b}$ & 93 & 0.23 \\
$\mathbf{2 c}$ & 78 & 0.23 \\
$\mathbf{2 d}^{\mathbf{c}}$ & $>99$ & 0.09
\end{tabular}

${ }^{a}$ Reaction conditions(except for $\mathbf{2 d}$ ), monomer 1a: $1 \mathrm{mmol}$, monomer 2: $1 \mathrm{mmol}, \mathrm{P}_{2} \mathrm{O}_{5}-\mathrm{MsOH}: 3 \mathrm{~g}$, $60^{\circ} \mathrm{C}, 24 \mathrm{~h}$. ${ }^{\mathrm{b}}$ Inherent viscosity was determined in a concentrated $\mathrm{H}_{2} \mathrm{SO}_{4}$ solution $\left(0.3 \mathrm{~g} \mathrm{dL}^{-1}\right)$ at $30^{\circ} \mathrm{C}$. ${ }^{\mathrm{c}}$ Reaction conditions: $80^{\circ} \mathrm{C}, 2 \mathrm{~h}$.

tone was $0.15 \mathrm{dL} \mathrm{g}^{-1}$. In addition, during the reaction at $30^{\circ} \mathrm{C}$, the reaction mixture was turned to deep red. As a matter of course, side reactions, e.g., attack of aromatic rings to carbonyl carbon, probably occurs at the temperature higher than $30^{\circ} \mathrm{C}$. Polymerization in other solvents such as $\mathrm{CH}_{2} \mathrm{Cl}_{2}, \mathrm{CHCl}_{3}$, and $\mathrm{PhNO}_{2}$ gave lowermolecular-weight polymer than that obtained in 1,2dichloroethane. ${ }^{22}$ On the other hand, isophthaloyl chloride (5c) and 2,6-naphthalenedicarbonyl chloride (5d) underwent the reaction with $2,2^{\prime}$-dimethoxybiphenyl (1a), affording polymers $\mathbf{6 c}$ and $\mathbf{6 d}$, respectively, with inherent viscosities of $0.24 \mathrm{dL} \mathrm{g}^{-1}$.

The results of the polymerization of $2,2^{\prime}-$ dimethoxybiphenyl (1a) shown in Tables II and III reveal that monomer 1a is also a suitable acylacceptant monomer for $\mathrm{AlCl}_{3}$-promoted Friedel-Crafts acylation polymerization with conventional arenedicarboxylic acids with no arylene ether units, which is just the structural requisite for synthesis of wholly aromatic polyketones. The preference of $\mathrm{AlCl}_{3}$-promoted 
Table III. $\mathrm{AlCl}_{3}$-mediated polymerization of 2,2'-dimethoxybiphenyl (1a) and dicarbonyl dichloride $\mathbf{5}^{\mathrm{a}}$

\begin{tabular}{cclcc}
\hline $\begin{array}{c}\text { Dicarbonyl } \\
\text { dichloride 5 }\end{array}$ & Polymer 6 & Solvent & Yield/\% & $\eta_{\text {inh }} / \mathrm{dL} \mathrm{g}^{-1 b}$ \\
\hline $\mathbf{5 b}$ & $\mathbf{6 b}$ & $\mathrm{ClCH}_{2} \mathrm{CH}_{2} \mathrm{Cl}$ & 99 & 0.68 \\
& & $\mathrm{CH}_{2} \mathrm{Cl}_{2}$ & 65 & 0.16 \\
& & $\mathrm{CHCl}_{3}$ & 75 & 0.19 \\
& & $\mathrm{PhNO}_{2}$ & 74 & 0.10 \\
$\mathbf{5 c}$ & \multirow{6}{*}{$\mathbf{c}$} & $\mathrm{ClCH}_{2} \mathrm{CH}_{2} \mathrm{Cl}$ & 78 & 0.24 \\
& & $\mathrm{CH}_{2} \mathrm{Cl}_{2}$ & 66 & 0.17 \\
& & $\mathrm{CHCl}_{3}$ & 71 & 0.13 \\
& & $\mathrm{PhNO}_{2}$ & 77 & 0.27 \\
5e & $\mathbf{6 e}$ & $\mathrm{ClCH}_{2} \mathrm{CH}_{2} \mathrm{Cl}$ & 78 & 0.24 \\
\hline
\end{tabular}

${ }^{\mathrm{a}}$ Reaction conditions, monomer 1a: $1 \mathrm{mmol}$, monomer 5: $1 \mathrm{mmol}$, $\mathrm{AlCl}_{3}$ : $2.7 \mathrm{mmol}$, Solvent: $4 \mathrm{~mL}, 20^{\circ} \mathrm{C}, 24 \mathrm{~h}$. ${ }^{\text {b Inherent viscosity was }}$ determined in a concentrated $\mathrm{H}_{2} \mathrm{SO}_{4}$ solution $\left(0.3 \mathrm{~g} \mathrm{dL}^{-1}\right)$ at $30^{\circ} \mathrm{C}$.

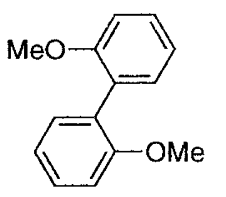

$1 \mathbf{a}$<smiles>O=C(Cl)OC(=O)Cl</smiles>

$5 b, c, e$
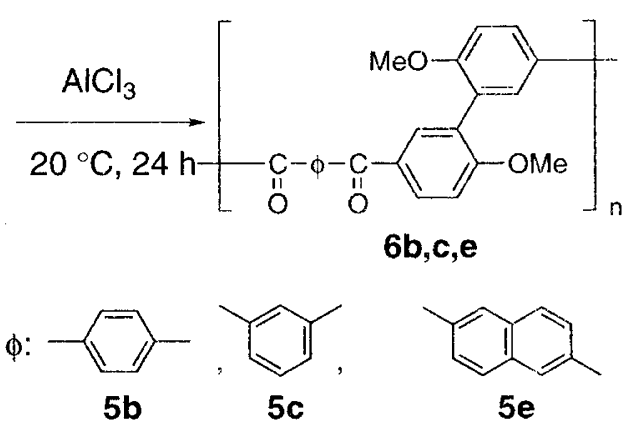

Scheme 3.

Friedel-Crafts acylation polymerization to $\mathrm{P}_{2} \mathrm{O}_{5}-$ $\mathrm{MsOH}$ mediated direct condensation polymerization probably depends on higher activation of carboxylic acids or their derivatives. As already described, the sufficient reactivity of arenedicarboxylic acid containing $\mathrm{CF}_{3}$ group (2d) in $\mathrm{P}_{2} \mathrm{O}_{5}-\mathrm{MsOH}$ mediated direct condensation polymerization is probably due to the electron-deficiency of the carbonyl groups of dicarboxylic acid itself.

\section{Thermal Property of Polymer 6}

On the basis of the DSC curves, $T_{\mathrm{g}}$ 's of the resulting polyketones were determined. Wholly aromatic polyketones $\mathbf{6 b}, \mathbf{6 c}$, and $\mathbf{6 e}$ show no melting points. The $p$-phenylenedicarbonyl skeleton of polymer $\mathbf{6 b}$ is considered to have more rigid than the $m$ phenylenedicarbonyl skeleton of polymer 6c. The different rigidities of the polyketones probably affect their $T_{\mathrm{g}}$ 's: $220^{\circ} \mathrm{C}$ for polymer $\mathbf{6 b}$ and $200^{\circ} \mathrm{C}$ for polymer $\mathbf{6 c}$. In addition, $T_{\mathrm{g}}$ of the poly(ether ketone) obtained in the reaction of diphenyl ether and terephthaloyl chloride
Table IV. Glass transition temperatures of aromatic polyketones $^{\mathrm{a}}$

\begin{tabular}{cccc}
\hline Monomers & Polymer & $\eta_{\text {inh }} / \mathrm{dL} \mathrm{g}^{-1 \mathrm{~b}}$ & $T_{\mathrm{g}} /{ }^{\circ} \mathrm{C}^{\mathrm{c}}$ \\
\hline $\mathbf{1 a}+\mathbf{5 b}$ & $\mathbf{6 b}$ & 0.68 & 222 \\
$\mathbf{1 a}+\mathbf{5 c}$ & $\mathbf{6 c}$ & 0.24 & 200 \\
$\mathbf{1 a}+\mathbf{5 e}$ & $\mathbf{6 e}$ & 0.24 & 217 \\
$\mathbf{1 a}+\mathbf{2 a}$ & $\mathbf{3 a}$ & 0.49 & 200 \\
$\mathbf{1 d}+\mathbf{5 b}$ & & 0.45 & 172 \\
\hline
\end{tabular}

${ }^{a}$ Reaction conditions, monomer 1: $1 \mathrm{mmol}$, monomer 5: $1 \mathrm{mmol}, \mathrm{AlCl}_{3}$ : $2.7 \mathrm{mmol}$, Solvent: $4 \mathrm{~mL}, 20^{\circ} \mathrm{C}, 24 \mathrm{~h}$. ${ }^{\mathrm{b}}$ Inherent viscosity was determined in a concentrated $\mathrm{H}_{2} \mathrm{SO}_{4}$ solution $\left(0.3 \mathrm{~g} \mathrm{dL}^{-1}\right)$ at $30^{\circ} \mathrm{C}^{\mathrm{c}}{ }^{\mathrm{g}} \mathrm{g}_{\mathrm{g}}$ was determined on the basis of DSC curves. Heating rate, $10 \mathrm{~K} \mathrm{~min}^{-1}$.

is $172^{\circ} \mathrm{C}$ and that of poly(ether ether ketone) (PEEK) is $143^{\circ} \mathrm{C}$. These values show that there is a tendency that decrease in the portion of ether linkage in the main chain increases $T_{\mathrm{g}}$. This tendency is accountable as follows: removal of flexible ether bond where free rotation occurs, improves thermal resistibility of the polyketone.

Thermal degradation temperature $\left(T_{\mathrm{d}}\right)$ of polymer 6b was determined on the basis on TGA thermograms recorded under nitrogen. The $5 \%$ weight loss of polymer $6 \mathbf{b}$ occurs at $418^{\circ} \mathrm{C}$. The thermal resistibility is almost the same as poly(ethylene terephthalate). The existence of methoxy group presumably incurs oxidation of methoxyarene moiety or thermal scission of the main chain. $^{23}$

\section{Copolymerization}

Two types of copolymerization about acyl-acceptant monomer 1a were undertaken to clarify the relationship between molecular structure and $T_{\mathrm{g}}$. One is the copolymerization of the combination of acyl-acceptant monomers 1a and 1d with terephthaloyl chloride (5b). The other is the copolymerization of acyl-acceptant monomer 1a with the combination of arenedicarboxylic acids $\mathbf{5 b}$ and $\mathbf{5 e}$. 
Table V. $\mathrm{AlCl}_{3}$-mediated copolymerization of arene $\mathbf{1}$ and dicarbonyl chloride $\mathbf{5}^{\mathrm{a}}$

\begin{tabular}{|c|c|c|c|c|c|}
\hline \multicolumn{4}{|c|}{ Monomer/mmol } & \multirow[t]{2}{*}{$\eta_{\text {inh }} / \mathrm{dL} \mathrm{g}^{-1 \mathrm{~b}}$} & \multirow[t]{2}{*}{$\overline{T_{\mathrm{g}} /{ }^{\circ} \mathrm{C}^{\mathrm{c}}}$} \\
\hline $1 \mathrm{a}$ & 1d & $5 \mathbf{b}$ & $5 e$ & & \\
\hline 1 & 0 & 1 & & 0.68 & 222 \\
\hline 0.8 & 0.2 & 1 & & 0.24 & 220 \\
\hline 0.5 & 0.5 & 1 & & 0.35 & 204 \\
\hline 0.2 & 0.8 & 1 & & 0.49 & 191 \\
\hline 0 & 1 & 1 & & 0.45 & 172 \\
\hline 1 & & 0.8 & 0.2 & 0.53 & 223 \\
\hline 1 & & 0.5 & 0.5 & 0.38 & 224 \\
\hline 1 & & 0.2 & 0.8 & 0.36 & 227 \\
\hline 1 & & 0 & 1 & 0.24 & 217 \\
\hline
\end{tabular}

aReaction conditions, $\mathrm{AlCl}_{3}: 2.7 \mathrm{mmol}$, Solvent: $4 \mathrm{~mL}$, $20^{\circ} \mathrm{C}, 24 \mathrm{~h}$. ${ }^{\mathrm{b}}$ Inherent viscosity was determined in a concentrated $\mathrm{H}_{2} \mathrm{SO}_{4}$ solution $\left(0.3 \mathrm{~g} \mathrm{dL}^{-1}\right)$ at $30^{\circ} \mathrm{C} .{ }^{\mathrm{c}} T_{\mathrm{g}}$ was determined on the basis of DSC curves. Heating rate, $10 \mathrm{~K} \mathrm{~min}^{-1}$.

The results of copolymerization of 2,2'-dimethoxybiphenyl (1a) and diphenyl ether (1d) with terephthaloyl chloride (5b) are shown in Table V. Increase in the portion of $2,2^{\prime}$-dimethoxybiphenylene unit gradually increases $T_{\mathrm{g}}$ of the copolymer. This is reasonably interpreted to be caused by the higher rigidity of 2,2 dimethoxy-5,5'-biphenylene than 4,4'-oxybiphenylene unit having ether bond.

The results of the copolymerization of terephthaloyl chloride (5b) and 2,6-naphthalenedicarbonyl chloride (5e) with 2,2'-dimethoxybiphenyl (1a) are also shown in Table V. These results imply that the $T_{\mathrm{g}}$ of the resulting copolymer decreases with increasing in the portion of 2,6-naphthalenedicarbonyl unit, which decreases the degree of polymerization at the same time. This behavior presumably owes to the lower solubility of the resulting polyketone in 1,2-dichloroethane.

\section{CONCLUSIONS}

We have succeeded in the synthesis of wholly aromatic polyketones using 2,2'-dimethoxybiphenyl (1a) as the acyl-acceptant monomer. For the synthesis of wholly aromatic polyketones bearing $2,2^{\prime}$-dimethoxy5,5'-biphenylene units except for those bearing $\mathrm{CF}_{3}$ groups, $\mathrm{AlCl}_{3}$-mediated Friedel-Crafts acylation is the superior method to $\mathrm{P}_{2} \mathrm{O}_{5}-\mathrm{MsOH}$ mediated direct polycondensation. The resulting wholly aromatic polyketones have higher $T_{\mathrm{g}}$ values than poly(ether ketone)s.

\section{REFERENCES}

1. N. Yonezawa, J. Synth. Org. Chem. Jpn., 53, 172 (1995).

2. M. J. Mullins and E. P. Woo, J. Macromol. Sci. Rev. Macromol. Chem. Phys., 27, 313 (1987).

3. M. Bochmann and K. Kelley, J. Chem. Soc., Chem. Commun., 532 (1989).

4. M. Rahahn, A. -D. Schlueter, and G. Wagner, Makromol. Chem., Rapid Commun., 11, 535 (1990).

5. J. S. Moore, Makromol. Chem., Rapid Commun., 13, 91 (1992).

6. M. Bochmann and J. Lu, J. Polym. Sci., Part A: Polym. Chem., 32, 2493 (1994).

7. N. Yonezawa and H. Nakamura, Polymer Applications, 46, 199 (1997).

8. M. Ueda and F. Ichikawa, Macromolecules, 23, 926 (1990).

9. N. Yonezawa, T. Ikezaki, H. Nakamura, and K. Maeyama, Macromolecules, 33, 8125 (2000).

10. M. Ueda and M. Sato, Macromolecules, 20, 2675 (1987).

11. M. Ueda, H. Sugita, and T. Waragai, Polym., J., 20, 433 (1988).

12. M. Ueda and M. Oda, Polym., J., 21, 673 (1989).

13. M. Ueda, SYNLETT, 605 (1992).

14. N. Yonezawa, S. Mori, S. Miyata, Y. Ueha-Anyashiki, and K. Maeyama, React. Funct. Polym., 53, 11 (2002).

15. N. Yonezawa, S. Miyata, T. Nakamura, S. Mori, Y. Ueha, and R. Katakai, Macromolecules, 26, 5262 (1993).

16. N. Yonezawa, T. Namie, T. Ikezaki, T. Hino, H. Nakamura, Y. Tokita, and R. Katakai, React. Funct. Polym., 30, 261 (1996).

17. K. Maeyama, T. Namie, H. Nakamura, and, N. Yonezawa, Recent Progress in Polycondensation, 173 (2002).

18. N. Yonezawa, T. Hino, T. Namie, and R. Katakai, Synth. Commun., 26, 1575 (1996).

19. T. Hino, T. Namie, H. Nakamura, and N. Yonezawa, Nippon Kagaku Kaishi, 219 (2002).

20. P. E. Eaton, G. R. Carson, and J. T. Lee, J. Org. Chem., 38, 4071 (1976).

21. N. Yonezawa, H. Nakamura, and K. Maeyama, React. Funct. Polym., 52, 19 (2002).

22. M. J. Mullins and E. P. Woo, Macromol. Chem. Phys., 27, 313 (1987).

23. For the synthesis of wholly aromatic polyketone without ether linkages, see:

a) K. Maeyama, T. Ohe, H. Nakamura, and N. Yonezawa, Polym. J., 35, 290 (2003).

b) K. Maeyama, T. Ohe, H. Nakamura, and N. Yonezawa, Polym. J., 35, 1009 (2003). 